\title{
Effect of fenofibrate on brain infarction, brain swelling and edema in focal-transient cerebral ischemia in rat
}

Hadi Vahidi $^{1}$, Shima Shahyad ${ }^{2}$, Ali Noroozzadeh ${ }^{3}$, Mohammad Taghi Mohammadi ${ }^{4}$

$1 \wedge$ Sc Student, Department of Physiology and Medical Physics, School of Medicine, Baqiyatallah University of Medical Sci nces, Tehran, Iran. ORCID ID: 0000-0003-4197-1420

2.Assistant Professor, Neuroscience Research Center, Baqiyatallah University of Medical Sciences, Tehran, Iran. ORCID ID: 0000-0002-5483-5367

3.Assistant Professor, Department of Physiology and Medical Physics, School of Medicine, Baqiyatallah University of Medical Sciences, Tehran, Iran. ORCID ID: 0000-0003-4320-3273

4.Professor, Department of Physiology and Medical Physics, School of Medicine, Baqiyatallah University of Medical Sciences, Tehran, Iran., (Corresponding Author), Tel: +98-21-87555419, Email: Mohammadi.mohammadt@yahoo.com, ORCID ID: 0000-0003-0202-4236

\begin{abstract}
Background and Aim: Increasing evidence has demonstrated that activation of peroxisome proliferator-activated receptor alpha (PPAR $\alpha$ ), which belongs to the nuclear receptor family of ligand-activated transcription factors, after cerebral ischemia exhibit neuroprotective functions including anti-oxidative, anti-apoptotic and anti-inflammatory effects. The aim of this study was to evaluate the pretreatment effects of PPAR $\alpha$ agonist, fenofibrate, on brain infarction, tissue swelling and brain edema in an experimental model of ischemic stroke.

Materials and Methods: The study included three groups of rats $(\mathrm{N}=36)$; sham, control ischemic and treated ischemic groups. Brain ischemia was induced by 90 min middle cerebral artery occlusion (MCAO) followed by 24 hours reperfusion. Rats received fenofibrate (200 $\mathrm{mg} / \mathrm{kg} /$ day) by oral route for 4 days before induction of MCAO. Neurological deficit score (NDS), infarct volume (TTC staining method), tissue swelling and brain edema were assessed 24 hours after termination of MCAO.

Results: MCAO induced neurological dysfunction (2.83 \pm 0.16$)$, brain infarction $(282 \pm 30$ $\left.\mathrm{mm}^{3}\right)$, brain swelling $(15.13 \pm 2.29 \%)$ and edema $(17.23 \pm 1.97 \%)$ in control ischemic group. Administration of fenofibrate in the treated ischemic rats significantly reduced neurological dysfunction $(2.14 \pm 0.14)$, brain infarction $\left(92 \pm 28 \mathrm{~mm}^{3}\right)$, brain swelling $(4.35 \pm 1.42 \%)$ and edema (5.49 \pm 1.44$)$ compared to the rats in the control ischemic group.

Conclusion: Our findings indicated that activation of PPAR $\alpha$ by specific agonist, fenofibrate, effectively decreased the cerebral ischemia-reperfusion injuries as well as brain swelling and edema in an experimental model of ischemic stroke.

Keywords: Ischemic stroke, Fenofibrate, PPAR $\alpha$, Brain infarction, Brain edema

Received: Dec 18, $2018 \quad$ Accepted: Feb 7, 2021

How to cite the article: Hadi Vahidi, Shima Shahyad, Ali Noroozzadeh, Mohammad Taghi Mohammadi . Effect of Fenofibrate on Brain Infarction, Brain Swelling and Edema in Focal-Transient Cerebral Ischemia in Rat .SJKU. 2021;26(4):1-16.
\end{abstract}

Copyright (C) 2018 the Author (s). Published by Kurdistan University of Medical Sciences. This is an open access article distributed under the terms of the Creative Commons Attribution-Non Commercial License 4.0 (CCBYNC), where it is permissible to download, share, remix, transform, and buildup the work provided it is properly cited. The work cannot be used commercially without permission from the journal 


\section{تأثير فنوفيبرات بر ميزان ضايعه، تورم مغزى و ادم در مدل ايسكمى موضعى- موقتى مغز در موش صحرايى}

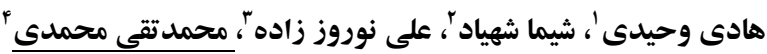

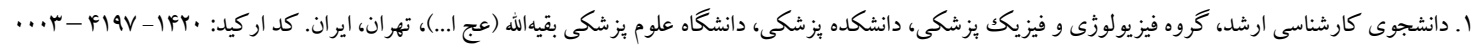

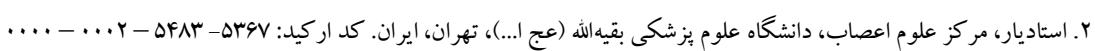
r.

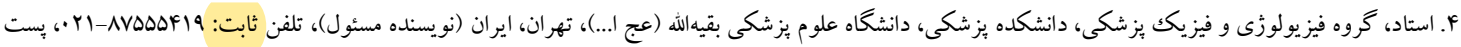

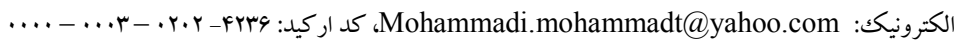

جـكيده زمينه و هدف: شو اهد رو بهرشدى نشان دادهاند فعال كردن گيرنده فعال كننده بروليفر اسيون برو كسيزوم آلفا (PPARa)، كه به

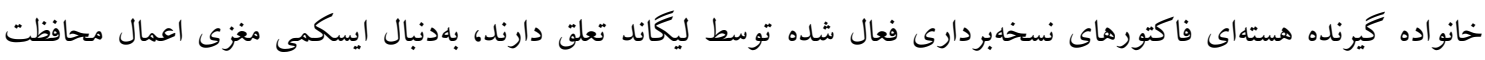

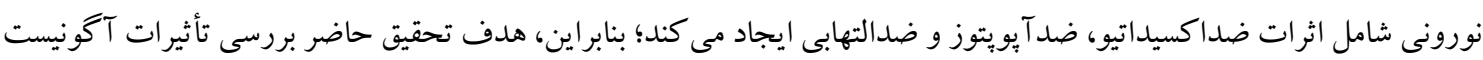
PPAR

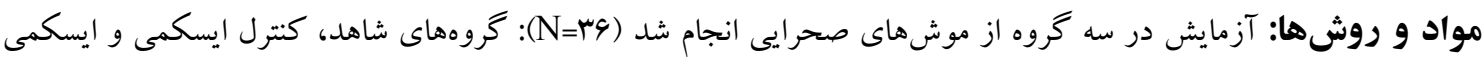

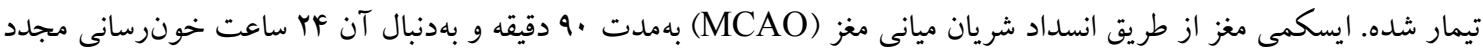

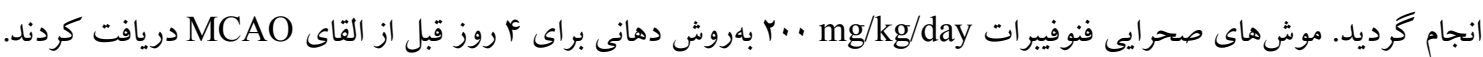

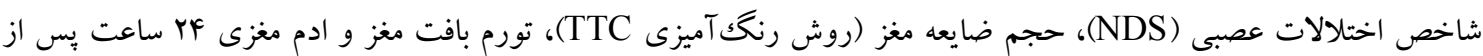

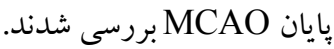

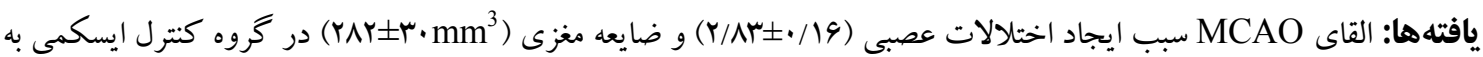

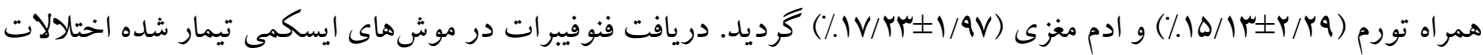

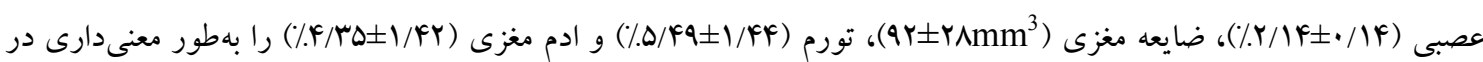

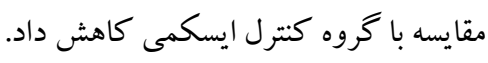
نتيجه كيرى: يافتهاى ما نشان داد كه فعالسازى PPARa توسط آكونيست اختصاصى، فنوفيبرات، بهور مؤثرى آسيبهاى

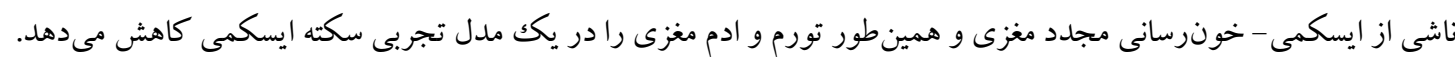

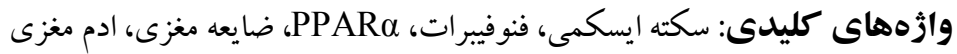
وصول مقاله :9V/9/YV اصلاحيه نهايى:99/II/IF يذيرش:99/11/19 


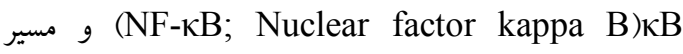
سيكنالى Activator protein 1) AP-1) باسخ هاى التهابى را در بافت مغز سركوب مىنمايد(rا, · •). فعال كردن اين

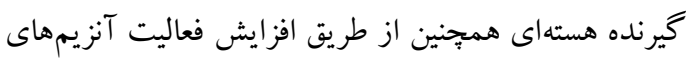

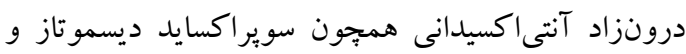

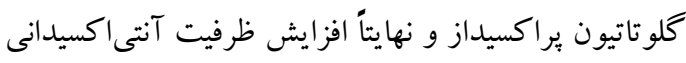

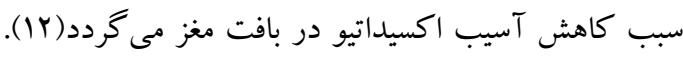

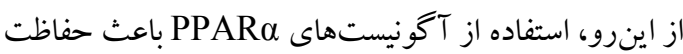

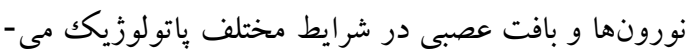
كردد (V) بر اساس نتايج مطالعات، فعالسازى PPARم در بافت

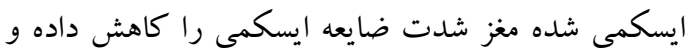

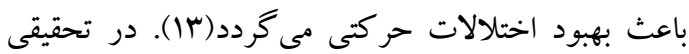

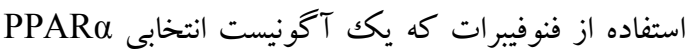

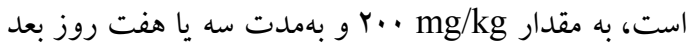
از القاى ايسكمى مغز آسيبهاى حر كتى، تغييرات حافظه، تخريب عروق و فر آيند التهاب را كاهش داده و همراه با لتابل

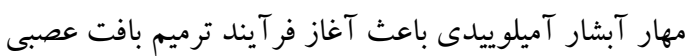

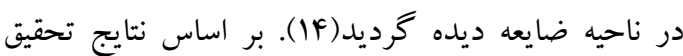

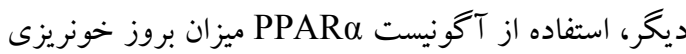

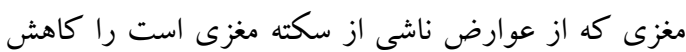
داده و باعث كاهش ضايعه مغزى، نفوذ نوتروفيل ها به بافت

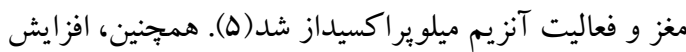
بيان زن PPAR از طريق تغيير عوامل هموديناميكك مغز همجيون جريان خون باعث ايجاد اثرات محافظت نورونى در

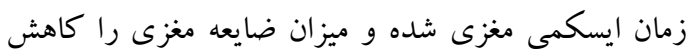

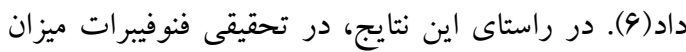

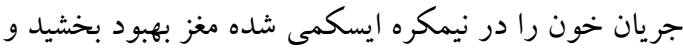
بدين طريق ميزان ضايعه ناشى از ايسكمى را كاهش داد (9).

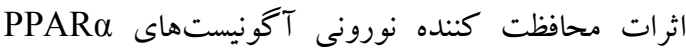
ماند فنوفيبرات در بيمارىهاى تخريب شونده بافت عصبى

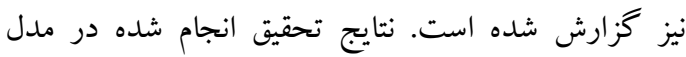

مقدمه ادم (خيز) مغز يكى از عوارض و ويامدهاى سكته مغزى است كه به دليل تجمع غيرطبيعى مايع در پارانشيم مغز ايجاد

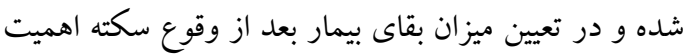

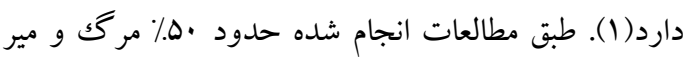

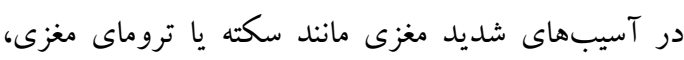

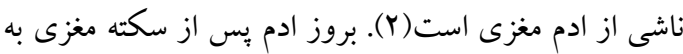

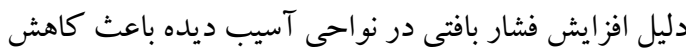

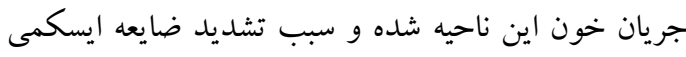

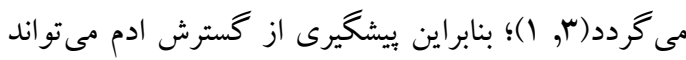

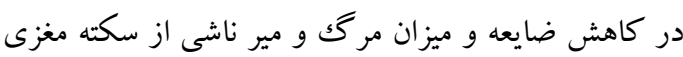

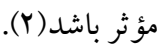

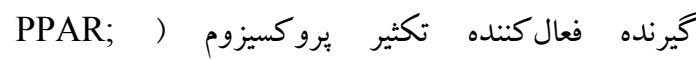
ز) (Peroxisome proliferator-activated receptor عوامل تنظيمى نسخهبردارى از زنهاى هستهاى بوده كه

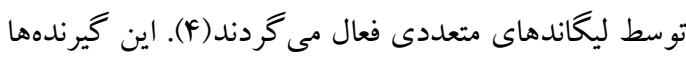

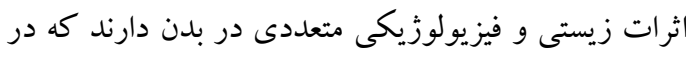
اين بين مىتوان به رشد، تمايز، مركى (آيويتوز)، التهاب،

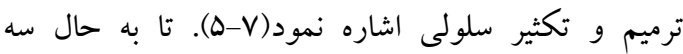

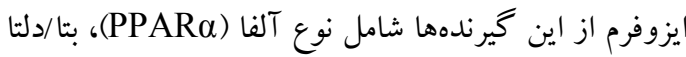

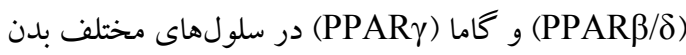

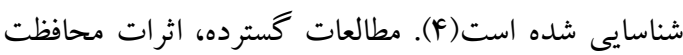

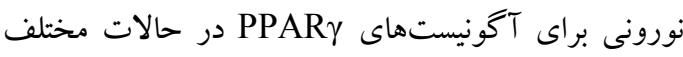

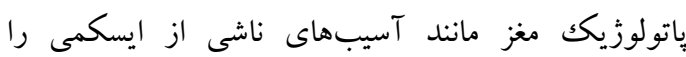

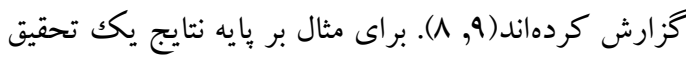

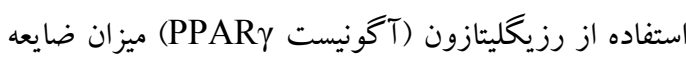

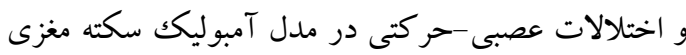
در موش صحرايى را به ميزان قابل توجهى كاهش داد(N).

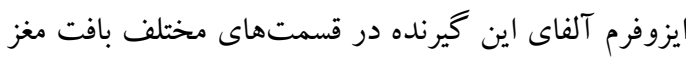
بيان شده و از طريق مختلف سبب اثرات محافظت نورونى

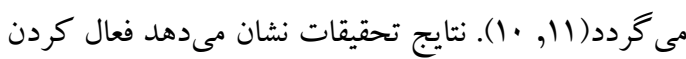
PPARa 


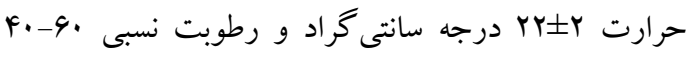
درصد) در طى آزمايش نخهدارى شدند. جهت انجام

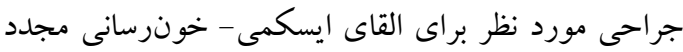

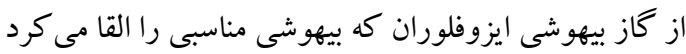

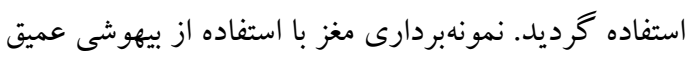

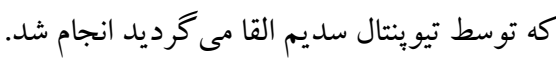
القاى ايسكمى موضعى - موقتى مغزى: براى آمادهازى حيوان جهت ايجاد ايسكمى موقتىموضعى مغز از روش ارائه شده توسط Longa و همكاران

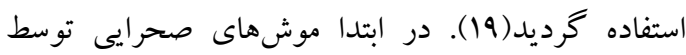

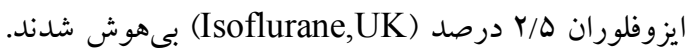

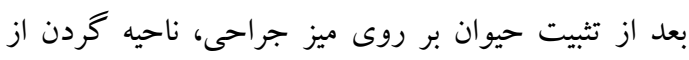
وسط باز شده و بافت همبند و عضلات را كنار زده تا مكان

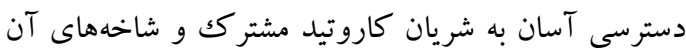

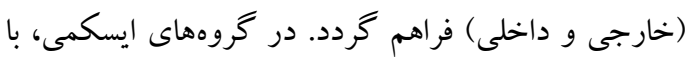

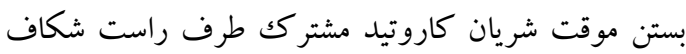
ظريفى در شاخه كاروتيد خارجى ايجاد نموده و همزمان با

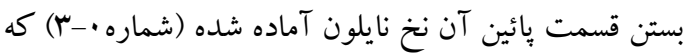
نوكى آن توسط حرارت گرد شده و سطح آن با بلى الى نائل ليزين يوشانده شده را از راه شكاف وارد شريان داخلى و از

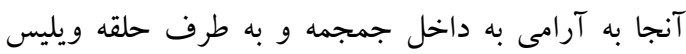
هدايت كرده تا به ابتداى شريان ميانى مغز برسد. با عبور

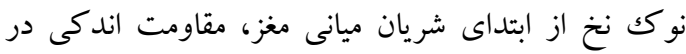

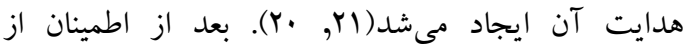

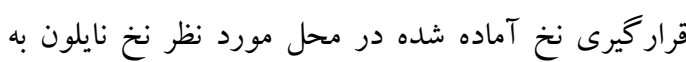

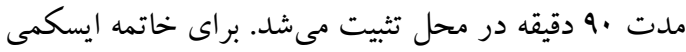

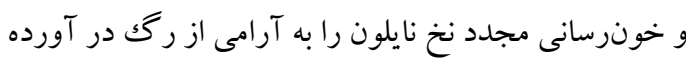
و با بستن شريان خارجى زخمهاى ايجاد شده در ناحيه

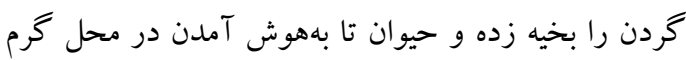

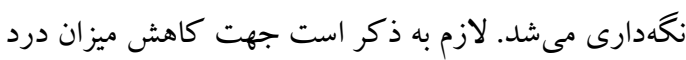

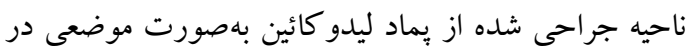

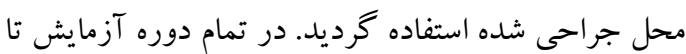

حيوانى بيمارى هانتينكتون نشان داد تيمار با فنوفيبرات قبل از

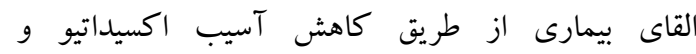
سيتو كاينهاى بيش التهابى در بافت مغز سبب بهبود علائم

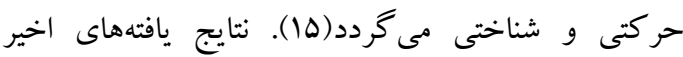

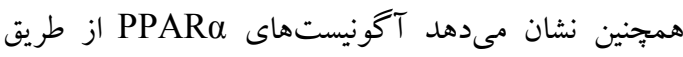

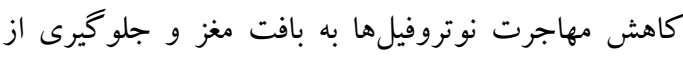

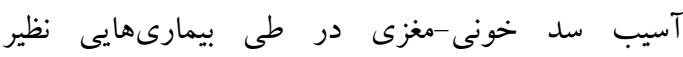

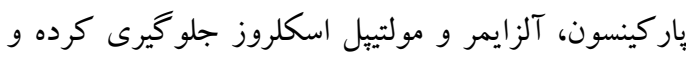
باعث محافظت نورونى مى شود (1)-19). نهايتاً، افزايش بيان ميزان نوروتروفين را در بافت مغز بيشتر كرده و

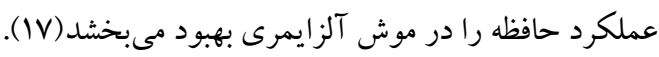

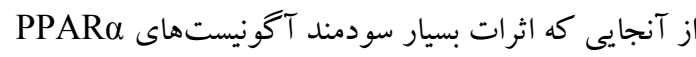

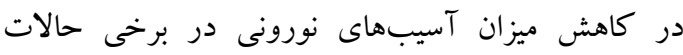

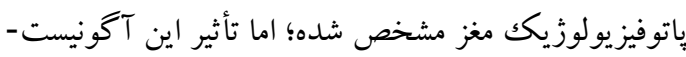

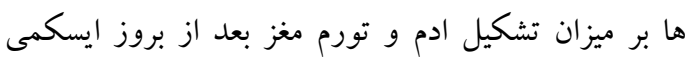

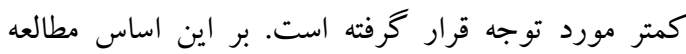

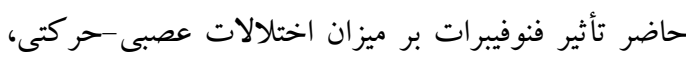

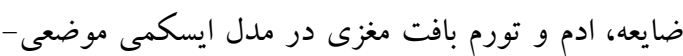
موقتى مغز در موش صحر ايى را مورد ارزيابى قرار داد.

مواد و روشها

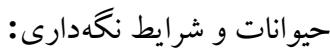

در اين تحقيق كه يك مطالعه مداخلهاى ـ تجربى بود، از موشهاى صحرايى نر نزاد ويستار تهيه شده از مركز

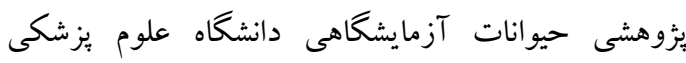

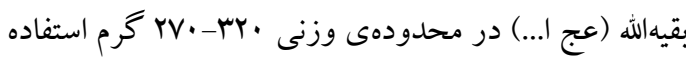

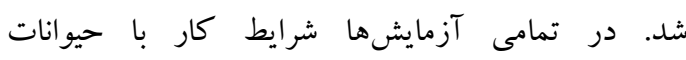
آزمايشگاهى تعيين شده، توسط كميته اخلاقى دانشكاه علوم

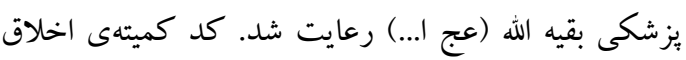

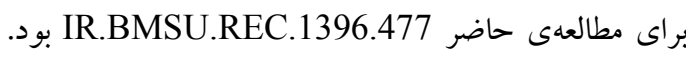

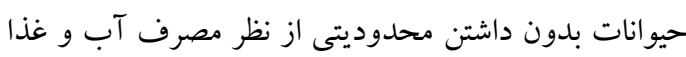

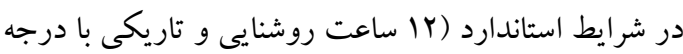

هجلم علهى دانشكاه علوه بِزشكى كردستان / دوره بيست و شش / هـر و آبان م.ع|| 
انسداد شريان ميانى مغز صورت نمى يذيرفت. با توجه به عدم انسداد شريان ميانى مغز، FF ساعت بعد از پايان جراحى هيج گونه علائم حاكى از ايسكمى مغزى مشاهده نشد. rكروه ايسكمى -خونرسانى مجدد ( IR, n=Ir): در حيوانات اين گروه كليه اعمال جراحى تا مرحله القاى ايسكمى مشابه كروه شاهد بود. القاى ايسكمى به مدت ·ه دقيقه دوام بيدا مى كرد و مرحله خونرسانى مجدد با بيرون كشيدن آهسته نخ شروع شده و بعد از ها دقيقه محل جراحى بخيه زده شده و حيوان در محل مناسب نكهدارى مىشد. ارزيابى اختلالات عصبى-حركتى MF ساعت بعد از شروع مرحله خونرسانى مجدد در حيواناتى كه زنده مىماندند، انجام مى گرديد. سيس تحت بىهوشى عميق، با تزريق داخل صفاقى تيوينتال سديم، حيوان را كشته، سر را جدا كرده و مغز را با احتياط كامل از جمجمه خارج نموده و جهت بررسى متغيرهاى مورد نظر آماده سازى شدند. ب- گروه ايسكمى-خونرسانى مجدد تيمار شده با فنوفيبرات

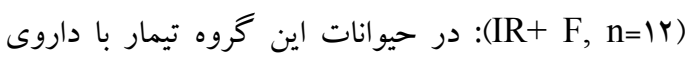
فنوفيبرات به ميزان r. mg/kg در روز بهمدت جهار روز

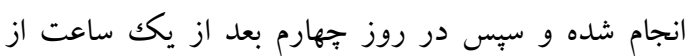
دريافت دارو جراحى جهت فيلامان گذارى براى القاى ايسكمى-خونرسانى مجدد همانند گروه كنترل ايسكمى خونرسانى مجدد انجام گرديد. ادامه بروتكلها و و اندازهكيرى متغيرهاى مد نظر عيناً شبيه به كروه كنترل ايسكمى خونرسانى مجدد انجام گرديد. لازم به ذكر است هر سه گرووه مطالعه بر پيايه نوع پيارامتر اندازه گيرى شده به دو زير كروه تقسيم شدند كه در يك زير گروه حجم ضايعه و تورم بافتى و در زير گروه ديخر ميزان ادم مغزى بر اساس بروتكلهاى ارائه شده اندازه خيرى مىشد. نتايج ارائه شده براى اختلالات عصبى -حر كتى نيز

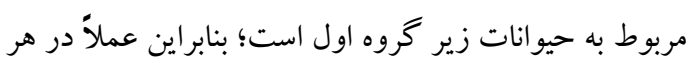
زير كروه نتايج 4 حيوان گزارش شده است. ارزيابى اختلالات عصبى -حر كتى:
خاتمه بىهوشى درجه حرارت حيوان با كمك لامب گرم

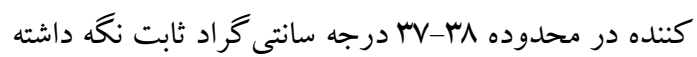
مىشد. بعد از هوشيارى كامل، حيوان به قفس منتقل شده و تا انجام آزمايش هاى بعدى در شر ايط مناسب نخهدارى شد. داروى مورد استفاده و روش مصرف آن: داروى مورد استفاده در اين تحقيق (فنوفيبرات) از شركت

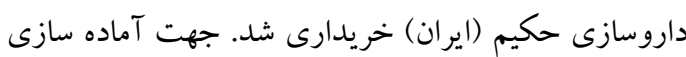
فنوفيبرات جهت مصرف حيوانات، ابتدا يودر داروى خريدارى شده توسط ترازوى دقيق ديجيتالى وزن شده و به صورت تازه در محلول كربو كسى متيل سلولز ه/ • درصد با كمكك ورتكس حل شد. در نهايت محلول تهيه شده بهصورت تازه و پيس از محاسبه مقدار تزريق (Y.. mg/kg) براى هر حيوان بهصورت دهانى و با كمك لوله مخصوص كاواز در موش صحرايى به حيوان داده مى شد. ميزان حجم تزريق بين ه/ • تا يكك ميلى ليتر بسته به وزن و محاسبات انجام شده بود كه معادل آن محلول كربو كسى متيل سلولز ه/ • درصد به حيوانات كروه شاهد و كنترل ايسكمى داده شد. يروتكل و گروههاى آزمايشى: يروتكل و كروههاى آزمايشى در اين تحقيق بهصورت زير

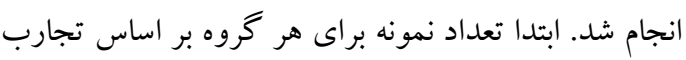
G- قبلى و زير نظر متخصص آمارى و با استفاده از نرم افزار Power

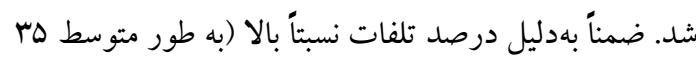
درصد) در اجراى طرح حاضر محدوديت تعداد نمونه براى هر كروه در نظر كرفته شد و نتايج مربوط به حيوانات تلفشده در طول مطالعه حذف گرديد. حيوانات مورد نظر بهصورت تصادفى در ب گروه به شرح زير قرار گرفتند: ا-

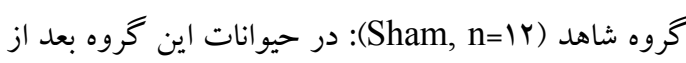
بيهوشى، عمل جراحى جهت انسداد شريان ميانى مغز با آشكارسازى شريان كاروتيد مشتر ك و شريانهاى كاروتيد خارجى و داخلى در ناحيه گردن انجام شده ولى عمل 
عكس گر فته و با استفاده از كامبيوتر و (Cannon, Japan) نرم افزار مخصوص (NIH image Analyzer) سطح ناحيه ضايعه ديده با روش ارائه شده در مطالعات قبلى حجم

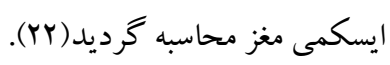$$
\text { اندازه گيرى درصد تورم بافتى: }
$$

Tissue swelling ( براى اندازه گيرى درصد توردل تورم بافئ (percent

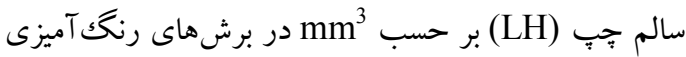
شده تعيين و درصد تورم بافتى با استفاده از فرمول زير

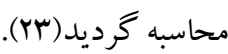

Tissue swelling $(\%)=[(\mathrm{RH}-\mathrm{LH}) / \mathrm{LH}] \times 100$

$$
\text { اندازه كيرى ميزان ادم مغزى: }
$$

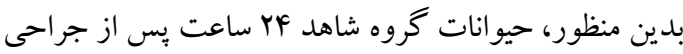
و گروههاى ايسكمى (كنترل ايسكمى و ايسكمى درمان

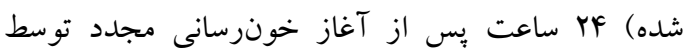

1- $\mathrm{H}_{2} \mathrm{O}(\%)=[(\mathrm{WW}-\mathrm{DW}) / \mathrm{WW}] \times 100$

2- $\quad$ Edema $(\%)=\mathrm{WC}_{\mathrm{RH}}(\%)-\mathrm{WC}_{\mathrm{LH}}(\%)$

كتامين به طور عميق بىهوش گرديدند. جهت اندازهيرى

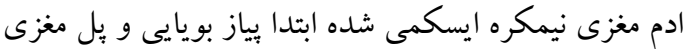
را جدا نموده و توسط ماتريكس مغزى و با دقت كامل مغز به دو نيمكره راست (ضايعه ديده) و جֶٍ (سالم) تقسيم مى شد. ابتدا، بهطور جداكانه وزن مرطوب (WW) دو نيمكره

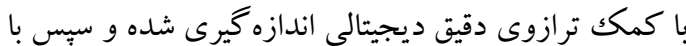
قرار دادن آنها در آون با درجه حرارت

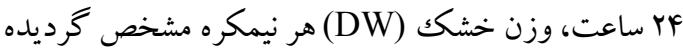
و با استفاده از فرمول ا درصد آب دو نيمكره راست (\%WC نهايت درصد ادم مغزى با استفاده از فرمول شماره Y در

$$
\begin{aligned}
& \text { كروههاى ايسكمى شده تعيين مى گرديد(YF). }
\end{aligned}
$$

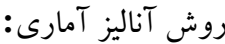

در حيواناتى كه تا YF ساعت بعد از بايان دوره ايسكمى

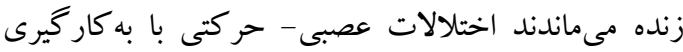

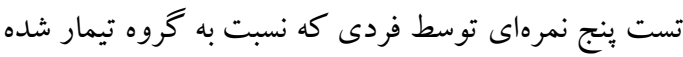

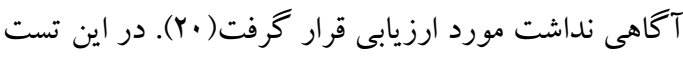
بهصورت قراردادى اختلالات عصبى- حركتى حيوان به شرح زير از نمره ا تا ها درجهبندى شده است. نمره 1 به

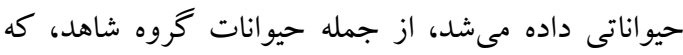

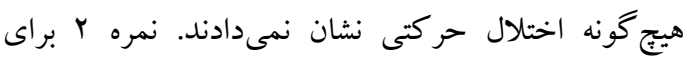

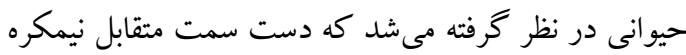

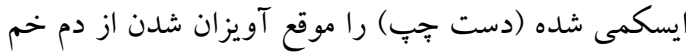
مىنمود (حالت Flexion). نمره ץ به حيوانى تعلق مى -

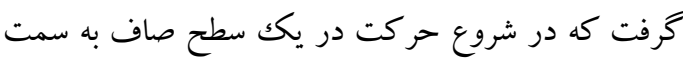

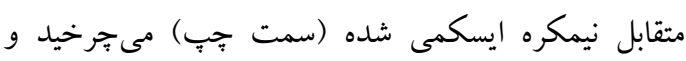
حيوانى كه رفلكس ايستادن را از دست داده بود نمره ثأو در نهايت نمره ها به حيواناتى داده مى شئ كه فاقد هر كر كونه حركت خودبخودى بودند. اندازه گيرى حجم ضايعه مغزى:

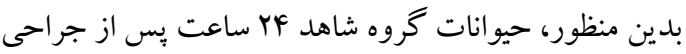
و گُروهاى ايسكمى (كنترل ايسكمى و ايسكمى درمان شده) MF ساعت بِ از آغاز خونرسانى مجدد توسط

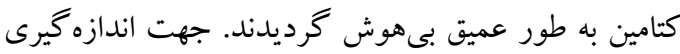

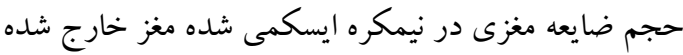
از جمجمه را براى سخت شدن به مدت ها دقيقه در نرمال سالين f درجه قرار داده و ستبس با استفاده از ماتريكس مغزى شش برش عرضى (Coronal) به قطر r ميلى متر تهيه

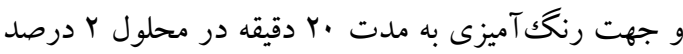

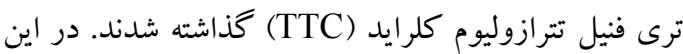
روش رنغك آميزى، ناحيه ايسكمى شده مغز به رنغك سفيد و

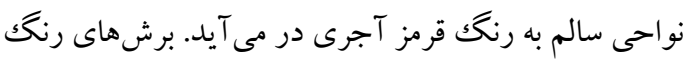
1. شده را جهت تثبيت شدن به مدت بو ساعت در فرمالين درصد بافر شده قرار داده و بعد از آماده سازى نهايى، از هر شش برش بهطور جداكانه توسط دوربين ديجيتال

هبله علمى دانشكاه علوه يِشكى كردستان / دوره بيست و شش / دمر و آبان م.ع|| 
(جدول ه و 9) در جداول مربوطه ارائه شده است. همبنين براى مقايسه دادههاى اختلالات عصبى-حركتى بهدليل ماهيت نوع دادهها (كمى-رتبهاى) از روش مقايسهاى غيريارامتريك (Nonparametric) و تست آمارى -Mann) Whitney U ميانگين 土 خطاى استاندارد ميانخين (Mean I SEM) ارائه شده است. در تمامى مقايسهها هـ/ P P بهعنوان اختلاف معنى دار تلقى گرديد.
در مطالعه حاضر جهت انجام آناليز آمارى از نرمافزار SPSS كولموگروف اسميرنف استه (Kolmogorov-Smirnov) دادههاى مطالعه از نظر توزيع نرمال ارزيابى شدند. بر اين اساس، براى مقايسه دادههايى كه داراى توزيع نرمال بودند

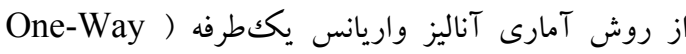
و از تست تعقيب TukOVA شد كه نتايج مربوطه براى يارامترهاى حجم ضايعه مغزى (جدول ا و Y)، تورم مغز (جدول r و \&) و ادم مغزى

جدول ا. دادههاى توصيفى نتايج مربوط به حجم ضايعه مغزى در كروههاى مطالعه

هبله علمى دانشكاه علوه بِزشكى كردستان / دوره بيست و شش / دهر و آبان م.ع|| 
ثاثير فنوفيبرات بر ميزان ضايعم...

جدول ه. دادههاى توصيفى نتايج مربوط به تشكيل ادم مغزى در كروههاى مطالعه

\begin{tabular}{|c|c|c|c|c|}
\hline خطاى استاندارد & $\begin{array}{c}\text { انحر اف معيار } \\
\text { (استاندارد) }\end{array}$ & ميانكين & تعداد & كروه \\
\hline$\cdot|\wedge \Delta|$ & $r / \cdot \wedge \Delta$ & $\cdot / \cdot \Delta r$ & 9 & شاهد \\
\hline $1 / 9 \vee \wedge$ & $F / A F \Delta$ & IV/rMq & 9 & ايسكمى - خونرسانى مجدد \\
\hline I/FYG & r/far & $f / r \Delta$ & 9 & ايسكمى - خونر شده بانى فنوفيبر ات مجدد \\
\hline
\end{tabular}

\begin{tabular}{|c|c|c|c|c|c|}
\hline Sig & $\mathbf{F}$ & مجذور ميانغين & درجه آزادى & مجموع مجذورات & \\
\hline \multirow{3}{*}{$\% \cdots$} & \multirow{3}{*}{$r \Delta / \wedge v q$} & FVN/GK. & r & $Q \Delta V / r \Lambda$. & بين گروهى \\
\hline & & IT/MFY & 10 & $r \cdots / T Y F$ & درون گروهى \\
\hline & & - & iv & $\| \Delta V / F \cdot F$ & كل \\
\hline
\end{tabular}

جدول Y. نتايج آزمون تعقيبى توكى بعد از تحليل آناليز واريان يككطرفه همراه با سطح اختلافهاى معنىدارى بين كروهها براى

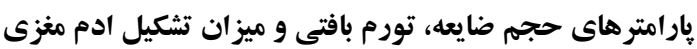

\begin{tabular}{|c|c|c|c|}
\hline سطح معنىدارى & كروه & كروه & متغيير هاى وابسته \\
\hline$\cdot \cdots$ & ايسكمى - خون رسانى مجدد & 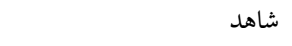 & \multirow{3}{*}{$\begin{array}{r}\text { حجم ضايعه مغزى } \\
\left(\mathbf{m m}^{3}\right)\end{array}$} \\
\hline$\cdot / \cdot \mu$ & ايسكمى- خونرسانى مجدد تيمار شده & 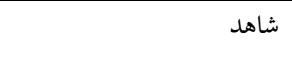 & \\
\hline.$/ \cdots$ & ايسكمى -خونرسانى مجدد تيمار شده & ايسكمى - خونرسانى مجدد & \\
\hline$\cdot \cdots$ & ايسكمى - خونرسانى مجدد & 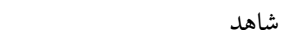 & \multirow{3}{*}{ تورم مغزى (.) } \\
\hline$\% \cdot v \Delta$ & ايسكمى - خونرسانى مجدد تيمار شده & 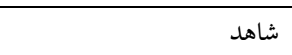 & \\
\hline 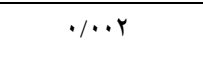 & ايسكمى-خونرسانى مجدد تيمار شده & ايسكمى- خونرسانى مجدد & \\
\hline.$/ \cdots$ & ايسكمى - خونرسانى مجدد & 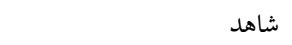 & \multirow{3}{*}{ ادم مغزى () ) } \\
\hline.$/|F|$ & ايسكمى-خونرسانى مجدد تيمار شده & شاهد & \\
\hline$\% \cdots$ & ايسكمى - خونرسانى مجدد تيمار شده & |يسكمى - خونرسانى مجدد & \\
\hline
\end{tabular}


كل را در اين گروه بهطور معنىدارى در مقايسه با گروه كنترل ايسكمى-خونرسانى مجدد كاهش داد (1) (P> (P) كه ميزان آن

$$
\text { نتايج درصد تورم بافتى: }
$$

همان طور كه نمودار بَ نشان مىدهد درصد تشكيل تورم مغزى نيمكره راست گروه شاهد كه با استفاده از حجم دمان نيمكرهها محاسبه شده بسيار كم و در حد صفر بود كه در كروه كنترل ايسكمى اين ميزان افزايش قابل ملاحظهاى

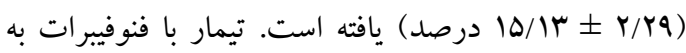

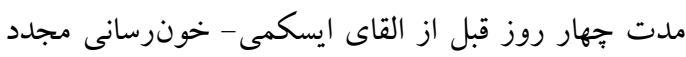
در گروه ايسكمى-خونرسانى مجدد درمان شده مقادير تورم نيمكره ايسكمى شده مغز را در خروه ايسكمى -خون رسانى مجدد درمان شده بهطور معنىدارى كاهش داد كه ميزان آن (P<•/.•1)

$$
\text { نتايج درصد ادم مغزى: }
$$

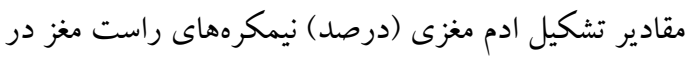

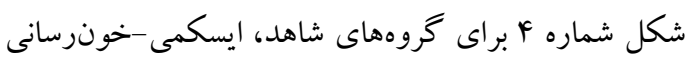

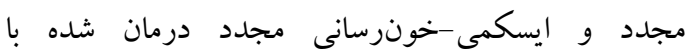
فنوفيبرات را نشان داده شده است. درصد تشكيل ادم مغزى در گروه شاهد در حد صفر بود. در حالى كه در خروان داده ايسكمى-خونرسانى مجدد اين ميزان افزايش قابل ملاحظه-

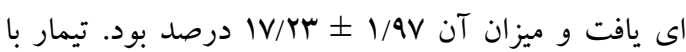

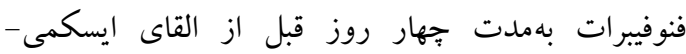
خونرسانى مجدد در گروه ايسكمى-خونرسانى مجدد

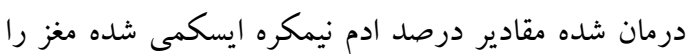

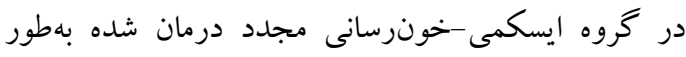

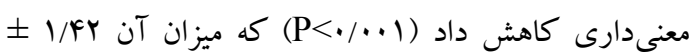

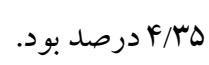

يافتهها نتايج اختلالات عصبى -حر كتى: نتايج حاصل از بررسى اختلالات عصبى -حر كتى در گروهـ-

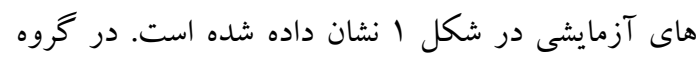

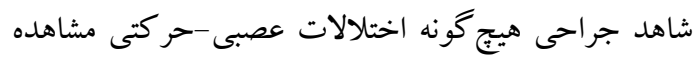

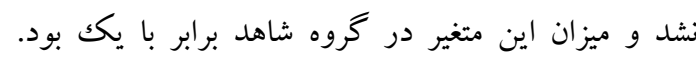

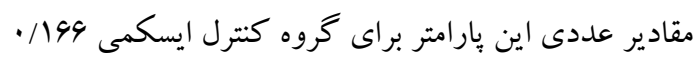

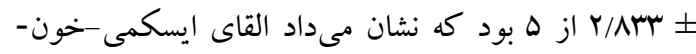
رسانى مجدد مغزى توانسته به مقدار زيادى اختلالات عصبى -حر كتى را در حيوانات اين گروه ايجاد نمايد. تيمار

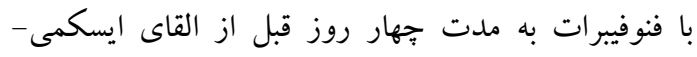

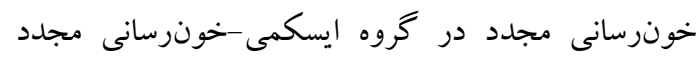

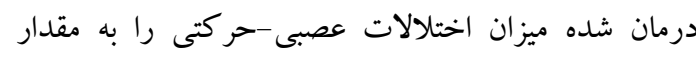

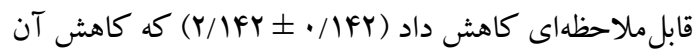

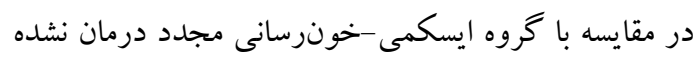

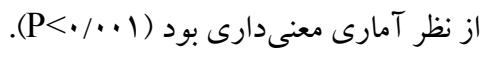

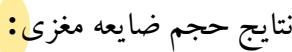
شكل شماره r مقادير كمى حجم ضايعه مغزى برى بر حسب

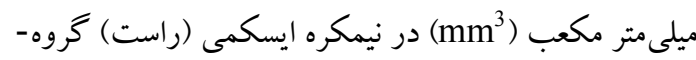

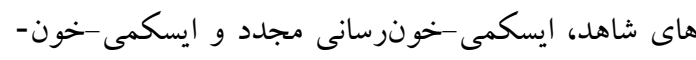

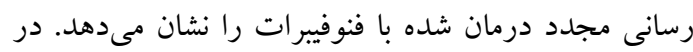

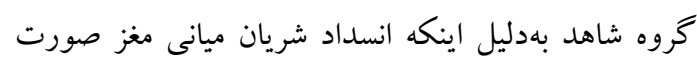

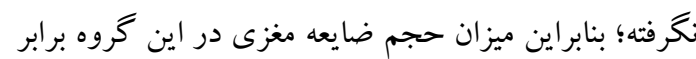
با صفر بود. القاء ايسكمى-خونرسانى مجدد توانسته ضايعه

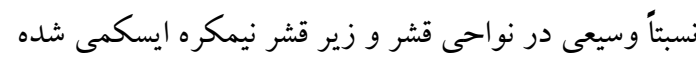

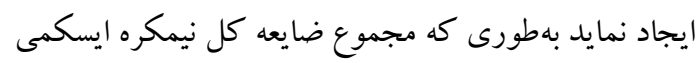

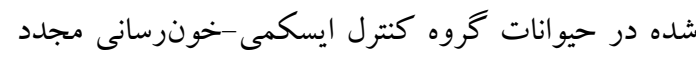
قار

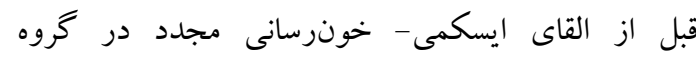
ايسكمى-خونرسانى مجدد درمان شده مقادير حجم ضايعه 


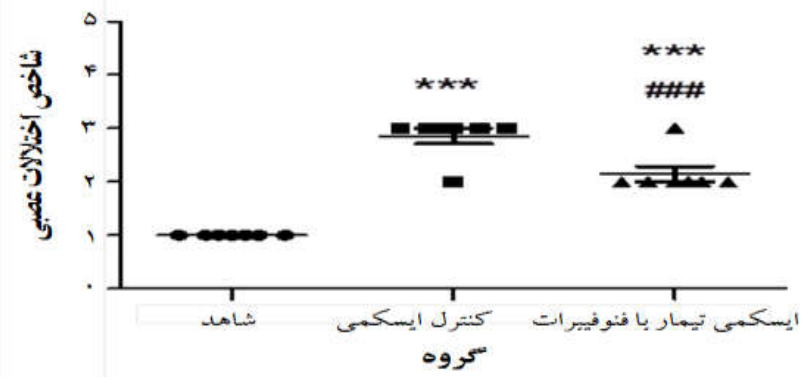

نمودار ا. شاخص اختلالات عصبى -حر كتى (ه-1) در بايان آزمايش در گروههاى شاهد، كنترل ايسكمى و ايسكمى تيمار شده با فنوفيبرات. دادهها به صورت means \pm SEM نشان داده شده است.

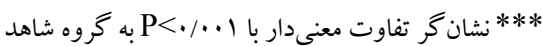

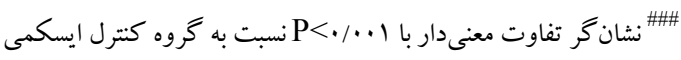

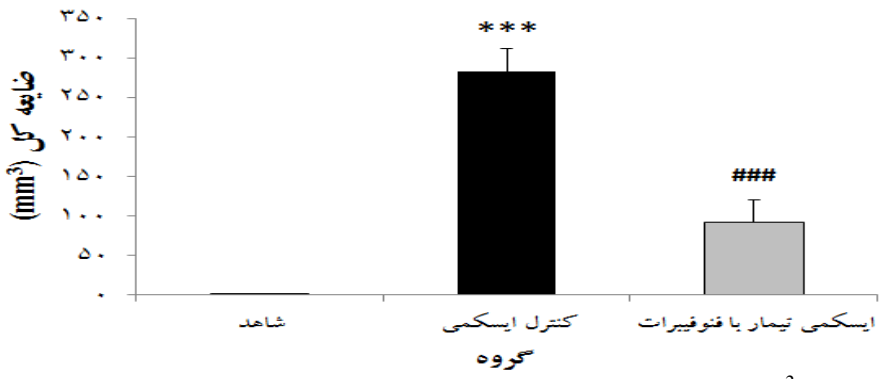

نمودار Y. مقادير حجم ضايعه مغزى (mm³) در پايان آزمايش در كروههاى شاهد، كنترل ايسكمى و ايسكمى تيمار شده با فنوفيبرات. دادهها به صورت means \pm SEM نشان داده شده است.

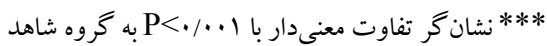

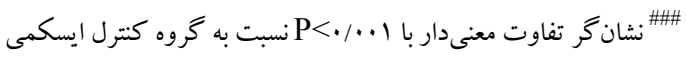

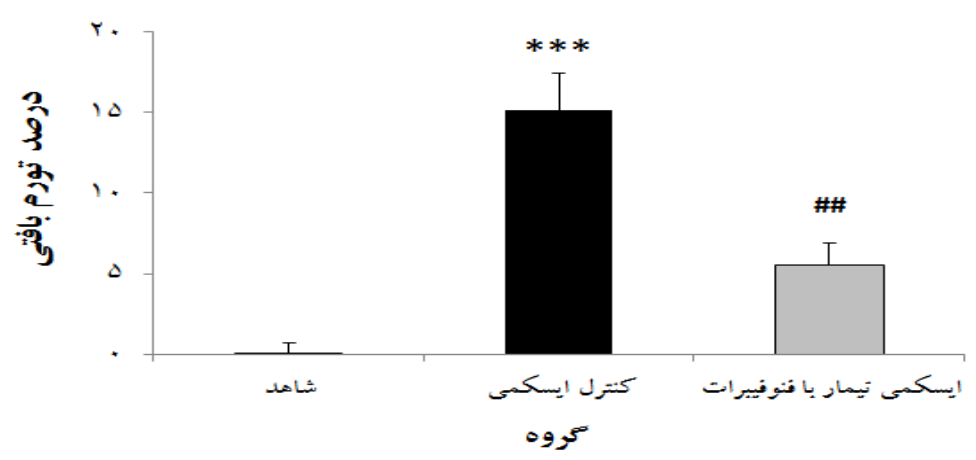

نمودار r. مقادير تشكيل تورم مغزى (درصد) در بايان آزمايش در گروههاى شاهد، كنترل ايسكى و ايسكمى تيمار شده با فنوفيبرات. دادهها به

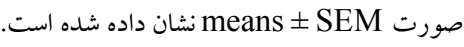

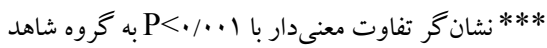

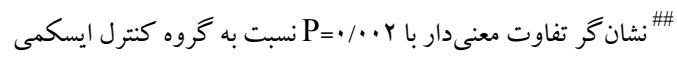




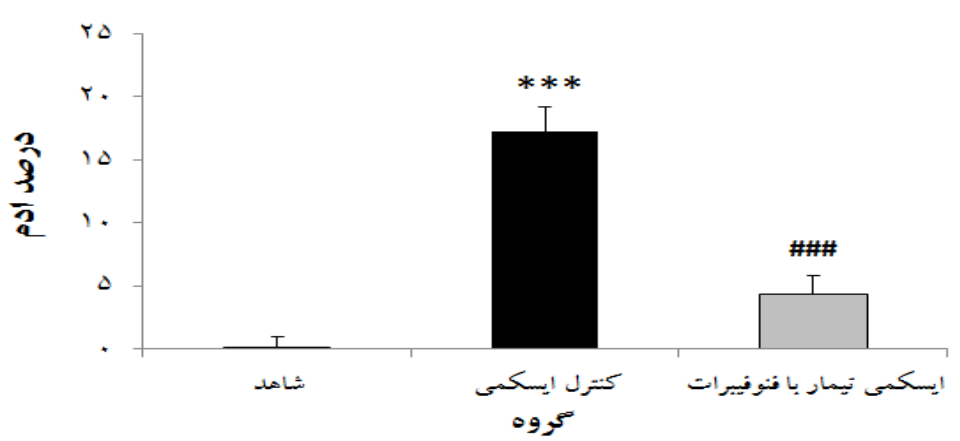

نمودار f. مقادير محاسبه شده ادم مغزى (درصد) در پايان آزمايش در گروههاى شاهد، كنترل ايسكمى و ايسكمى تيمار شده با فنوفيبرات. دادهها به صورت means \pm SEM نشان داده شده است.

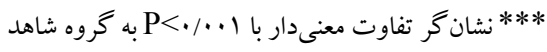

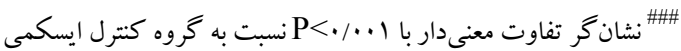

مطالعات انجام شده اخير، PPAR در قسمتهاى مختلف بافت مغز بيان شده و از طريق مختلف سبب اثرات محافظت نورونى مى گردد(11, ·1). اثرات محافظت كننده نورونى آگونيستهاى PPAR مانند فنوفيبرات و بهبود برخى علائم حركتى و شناختى در بيمارىهاى تخريب شونده بافت عصبى گزارش شده است(1/, ها). در مطالعهاى كه بر روى مدل حيوانى بيمارى هانتينگتون انجام شده نتايج به دست آمده نشان داد تيمار با آكونيست PPAR (فنوفيبرات) قبل از القاى بيمارى باعث بهبود علائم حركتى و شناختى گرديد(ها). در تحقيق ديخر كه بر روى مدل آزمايشگاهى بيمارى آلزايمر انجام شده استفاده از آكونيست PPAR و افزايش پِلاستيسيته سينايسى سبب بهبود حافظه و علائم عصبى -حر كتى شد( • (1). به نظر مىرسد فنوفيبرات، به عنوان يكك آكونيست PPAR Pاز طريت مسيرهاى مختلف مى تواند اختلال عصبى-حركتى ناشى از آسيب ايسكمىخونرسانى مجدد مغزى را كاهش دهد. براى مثال فعال كردن اين كيرنده هستهاى از طريق افزايش فعاليت آنزيمهاى درونزاد آنتىاكسيدانى همجيون سوبراكسايد ديسموتاز و كلوتاتيون براكسيداز و نهايتاً افزايش ظرفيت آنتى اكسيدانى سبب كاهش آسيب اكسيداتيو در بافت مغز

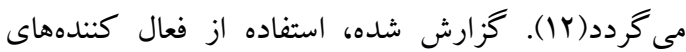

نتايج تحقيق حاضر نشان داد تيمار موشهاى صحرايى قبل از القاى ايسكمى مغزى با فنوفيبرات كه يكك آكونيست اختصاصى PPAR است، آسيبهاى ناشى از ايسكمىخونرسانى مجدد مغزى را به مقدار قابل توجهى كاهش مىدهد. بر اساس يافتهاى مطالعه حاضر تيمار با فنوفيبرات قبل از القاى ايسكمى بهمدت \&ٔ روز و بهصورت خوراكى ضايعه مغزى را به همراه اختلالات عصبى-حر كتى، در حيواناتى كه در آنها ضايعه ايسكمى ايجاد شده بود را بهطور معنى دارى كاهش داد. همجِنين ميزان تورم بافتى و تشكيل ادم مغزى در نيمكره ايسكمى شده حيوانات تيمار شده با فنوفيبرات در مقايسه با حيوانات گروه كنترل ايسكمى كاهش معنىدارى داشت. طبق اين نتايج به دست آمده تيمار با آكونيست اختصاصى PPAR مثل فنوفيبرات قادر است ميزان ضايعه مغزى و همجنين عوارض ناشى از آن همجون اختلالات عصبى-حر كتى، تورم و ادم مغزى ناشى از ايسكمى-خونرسانى مجدد مغزى را بهطور قابل ملاحظهاى كاهش دهد. در مطالعه حاضر، تيمار با فنوفيبرات قبل از القاى ايسكمى خونرسانى مجدد مغز باعث كاهش اختلالات عصبىحر كتى در حيوانات ايسكمى تيمار شده گرديد. بر يايه نتايج 
التهابى از طريق كاهش بيان سيتو كاين هاى التهابى مثل

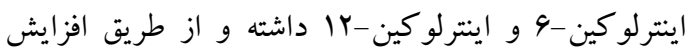

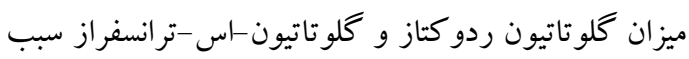
تقويت سيستم دفاع آنتىاكسيدانى و در نهايت سبب كاهش دون

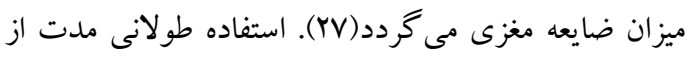

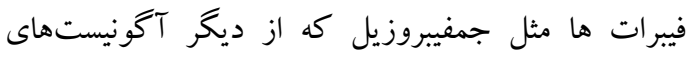
هستند توانسته ميزان فعاليت آنزيم سويراكسايد ديسموتاز را در بافت مغز افزايش داده و از بافت مغز در مقابل ضايعه ايسكمى محافظت نمايد(r). همجنين استفاده از آكونيست PPAR ميزان بروز خونريزى مغزى كه از عوارض ناشى از سكته مغزى بوده را كاهش داده و باعث

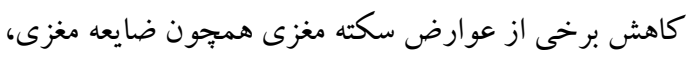
نفوذ نوتروفيل ها به بافت مغز، فعاليت آنزيم ميلويراكسيداز

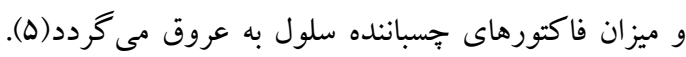

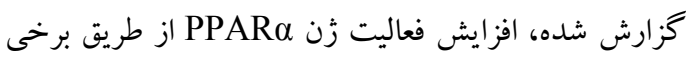

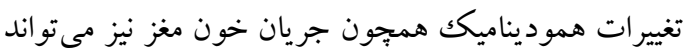

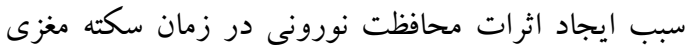

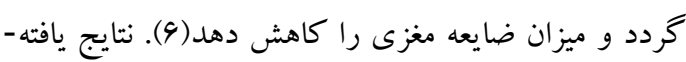
هاى Guo و همكاران ( • • (Y) نشان مىدهد فنوفيبرات ميزان

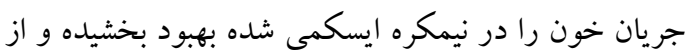

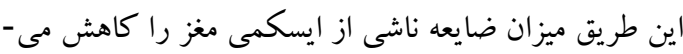

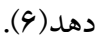

يافتهاى مطالعه حاضر نشان داد استفاده از فنوفيبرات قبل از

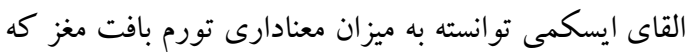

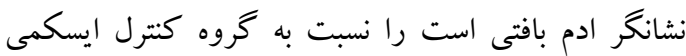

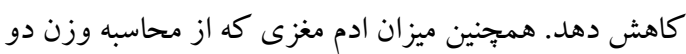

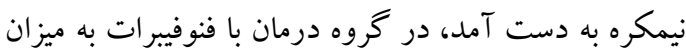
معنادارى كاهش يافت. در تحقيق مشابه كه بر روى اثرات

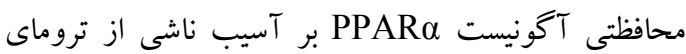
مغزى انجام شد استفاده از فنوفيبرات به دليل اثرات ضد

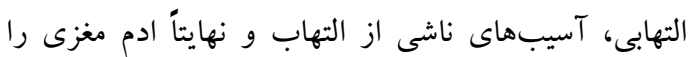

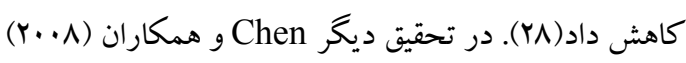

PPAR از طريق مهار التهاب بهواسطهى سيتو كاينها و فاكتورهاى بيش التهابى، اثرات محافظت نورونى اعمال

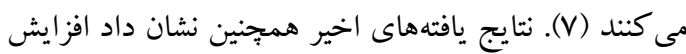

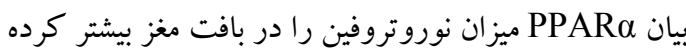

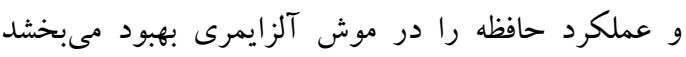

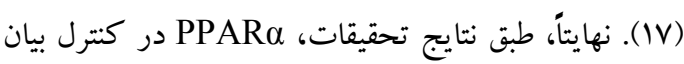

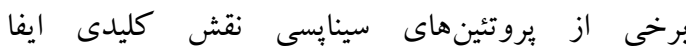

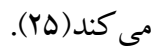

در مطالعه حاضر تيمار با فنوفيبرات قبل از القاى ايسكمى

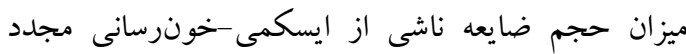

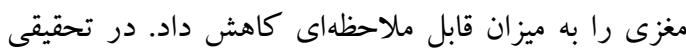
مشابه تيمار با فنوفيبرات با دوزهاى مختلف و بلهورت آنائ

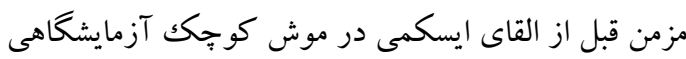
حجم ضايعه مغزى را كاهش داد(YI). نتايج تحقيق ديخر

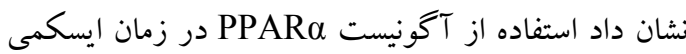
مغزى در كاهش ميزان خونريزى و ضايعه مغزى مؤثر است(ه). مشابه نتايج مطالعه حاضر كه در ايسكمى بافت مغز انجام شده در جندين مطالعه ديخر نيز اثرات محافظتى

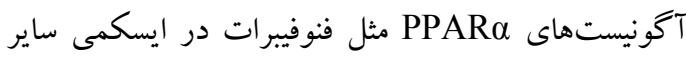
بافتهاى مختلف گزارش شده است. براى نمونه در

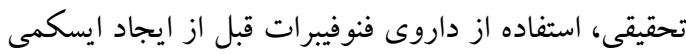

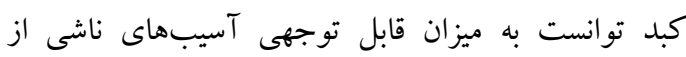
ايسكمى را در اين بافت كاهش داده و باعث بهبود عملكرد

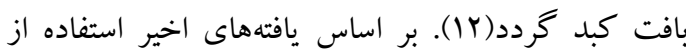

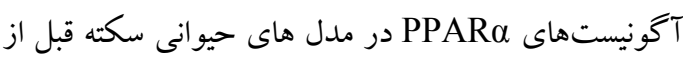
بروز ايسكمى مغزى از افزايش برخى فاكتورهاى مخرب

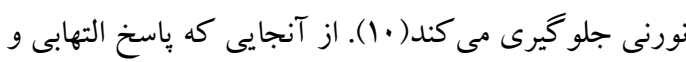
آسيب اكسيداتيو به همراه كاهش ظرفيت آنتى اكسيدانى

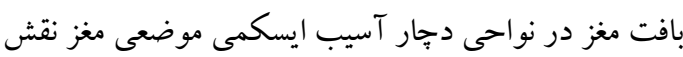

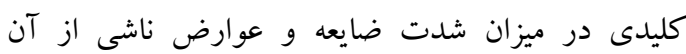

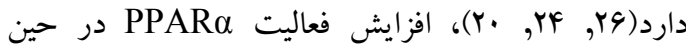

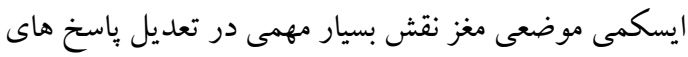




\section{نتيجه كيرى}

يافتهاى مطالعه حاضر نشان داد فعالسازى گيرنده فعال كننده تكثير يرو كسيزوم نوع آلفا (PPAR فنوفيبرات كه يك آكونيست PPARa به شمار مىرود

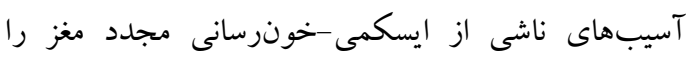

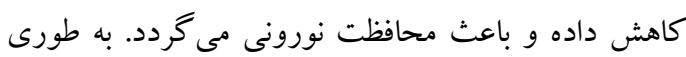

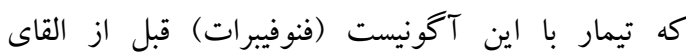

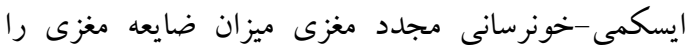

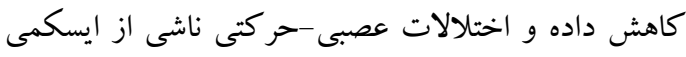
مغزى را به مقدار قابل ملاحظهاى بهبود مىبخشد. بعلاوه

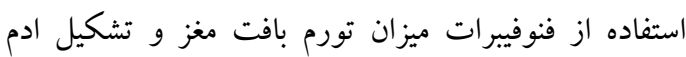

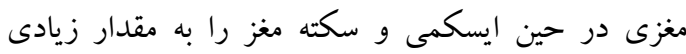

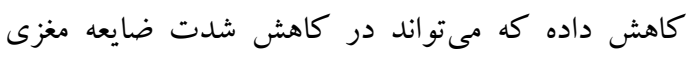

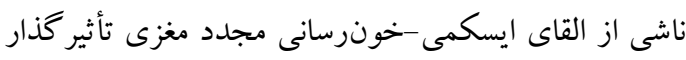

\section{تشكر و قدردانى}

اين مقاله حاصل نتايج بايانامه كارشناسى ارشد است. كد

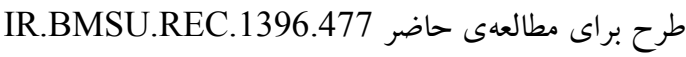
بود. بدينوسيله از اعضاى گروه فيزيولوزى و فيزيك

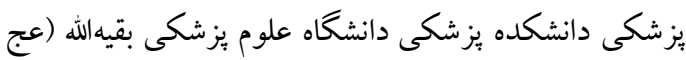
1...) كه مقدمات و وسايل مورد نياز اين تحقيق را فراهم نموده قدردانى مىشود. همجنين از معاونت يُزوهش

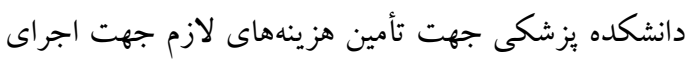
اين طرح صميمانه تقدير و تشكر مى گردد.
با استفاده همزمان از فنوفيبرات و سيمواستاتين در تروماى مغزى نشان دادند ميزان ادم مغزى به مقدار قابل توجهى لمثي كاهش يافته و باعث بهبود ضايعات حر كتى مى گردد (Y9). همجنين Zhu و همكاران (Y) (Y) در مطالعهاى كه اثر آكونيست PPAR بر روى آسيب بافت ريه توسط

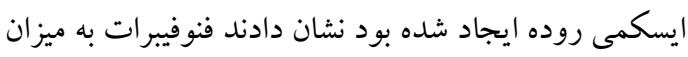
قابل توجهى ادم ناشى از اين ايسكمى كه در بافت ريه ايجاد

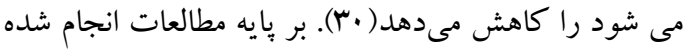

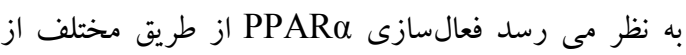
جمله كاهش التهاب، افزايش ظرفيت آنتىاكسيدانى بافت

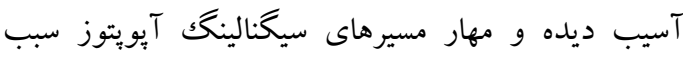
كاهش ادم مغزى ناشى از ايسكمى مغز مى گردد كه البته نياز به انجام تحقيقات جديد در زمينه مورد نظر دارد(بr, آسا).

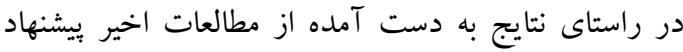

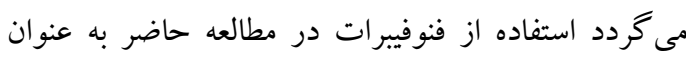

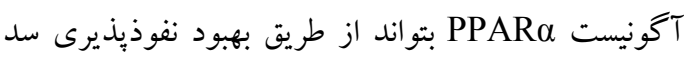
خونى-مغزى در حين ايسكمى-خونرسانى مجدد مغزى

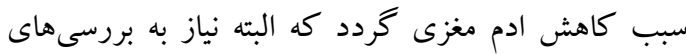
بيشترى دارد. در اين راستا در تحقيقى Gautier و همكار اندان (Y (Y) نشان دادند مداخله با فنوفيبرات مى تو اند فاكتورهاى التهابى دخيل در آسيب سد خونى-مغزى را كاهش دهد(با). در تحقيق ديخر استفاده از آكونيستهاى دري ميزان آسيب به سد خونى -مغزى در طى بيمارى سرطان ريه را كاهش داد(FF). همجِنين Sarnelli و

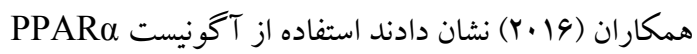
مىتواند پِاسخ التهابى در سلولهاى اندوتليال عروقى را بهبود بيخشد(ه).

منابع

1.Papadopoulos MC, Verkman AS. Aquaporin-4 and brain edema. Pediatr Nephrol. 2007;22(6):778-84.

2.Elger B, Seega J, Raschack M. Oedema reduction by levemopamil in focal cerebral ischaemia of spontaneously hypertensive rats studied by magnetic resonance imaging. Eur $\mathrm{J}$ Pharmacol. 1994;254(1-2):65-71.

هبله علدى دانشكاه علوه يِشكى كردستان / دوره بيست و شش / دهر و آبان م.ع|| 
3.Jha RM, Kochanek PM, Simard JM. Pathophysiology and treatment of cerebral edema in traumatic brain injury. Neuropharmacology. 2019;145:230-46.

4.Luo Y, He Q, Kuang G, Jiang Q, Yang J. PPAR-alpha and PPAR-beta expression changes in the hippocampus of rats undergoing global cerebral ischemia/reperfusion due to PPARgamma status. Behav Brain Funct. 2014;10(1):21.

5.Gautier S, Ouk T, Pétrault M, Pétrault O, Bérézowski V, Bordet R. PPAR-Alpha agonist used at the acute phase of experimental ischemic stroke reduces occurrence of thrombolysisinduced hemorrhage in rats. PPAR Res. 2015;2015:246329.

6.Guo Q, Wang G, Namura S. Fenofibrate improves cerebral blood flow after middle cerebral artery occlusion in mice. J Cereb Blood Flow Metab. 2010;30(1):70-8.

7.Villapol S. Roles of Peroxisome Proliferator-Activated Receptor Gamma on Brain and Peripheral Inflammation. Cell Mol Neurobiol. 2018;38(1):121-32.

8.Allahtavakoli M, Moloudi R, Arababadi MK, Shamsizadeh A, Javanmardi K. Delayed post ischemic treatment with Rosiglitazone attenuates infarct volume, neurological deficits and neutrophilia after embolic stroke in rat. Brain Res. 2009;1271:121-7.

9.Ding Y, Kang J, Liu S, Xu Y, Shao B. The Protective Effects of Peroxisome ProliferatorActivated Receptor Gamma in Cerebral Ischemia-Reperfusion Injury. Front Neurol. 2020;11:1469.

10.Gelé P, Vingtdeux V, Potey C, Drobecq H, Ghestem A, Melnyk P, et al. Recovery of brain biomarkers following peroxisome proliferator-activated receptor agonist neuroprotective treatment before ischemic stroke. Proteome Sci. 2014;12(1):24.

11.Chistyakov DV, Aleshin SE, Astakhova AA, Sergeeva MG, Reiser G. Regulation of peroxisome proliferator-activated receptors (PPAR) alpha and -gamma of rat brain astrocytes in the course of activation by toll-like receptor agonists. J Neurochem. 2015;134(1):113-24.

12.Wang G, Liu X, Guo Q,Namura S. Chronic treatment with fibrates elevates superoxide dismutase in adult mouse brain microvessels. Brain Res. 2010;1359:247-55.

13Li Y, Xu L, Zeng K, Xu Z, Suo D, Peng L, et al. Propane-2-sulfonic acid octadec-9-enylamide, a novel PPARalpha/gamma dual agonist, protects against ischemia-induced brain damage in mice by inhibiting inflammatory responses. Brain Behav Immun. 2017;66:289301.

14.Ouk T, Gautier S, Pétrault M, Montaigne D, Maréchal X, Masse I, et al. Effects of the PPAR- $\alpha$ agonist fenofibrate on acute and short-term consequences of brain ischemia. J Cereb Blood Flow Metab. 2014;34(3):542-51.

15.Bhateja DK, Dhull DK, Gill A, Sidhu A, Sharma S, Reddy BK, et al. Peroxisome proliferator-activated receptor- $\alpha$ activation attenuates 3-nitropropionic acid induced behavioral and biochemical alterations in rats: possible neuroprotective mechanisms. Eur J Pharmacol. 2012;674(1):33-43.

16.Deplanque D, Gelé P, Pétrault O, Six I, Furman C, Bouly M, et al. Peroxisome proliferator-activated receptor- $\alpha$ activation as a mechanism of preventive neuroprotection induced by chronic fenofibrate treatment. J Neurosci. 2003;23(15):6264-71.

17.Chang KL, Pee HN, Tan WP, Dawe GS, Holmes E, Nicholson JK, et al. Metabolic profiling of CHO-AbetaPP695 cells revealed mitochondrial dysfunction prior to amyloid-beta pathology and potential therapeutic effects of both PPARgamma and PPARalpha Agonisms for Alzheimer's disease. J Alzheimers Dis. 2015;44(1):215-31.

18.Barbiero JK, Santiago RM, Persike DS, da Silva Fernandes MJ, Tonin FS, da Cunha C, et al. Neuroprotective effects of peroxisome proliferator-activated receptor alpha and gamma

هبلم علدى دانشكاه علوه بِزشكى كردستان / دوره بيست و شش / دهر و آبان م.ع|| 
agonists in model of parkinsonism induced by intranigral 1-methyl-4-phenyl-1,2,3,6tetrahyropyridine. Behav Brain Res. 2014;274:390-9.

19.Longa EZ, Weinstein PR, Carlson S, Cummins R. Reversible middle cerebral artery occlusion without craniectomy in rats. Stroke. 1989;20(1):84-91.

20.Sarami Foroshani M, Sobhani ZS, Mohammadi MT, Aryafar M. Fullerenol Nanoparticles Decrease Blood-Brain Barrier Interruption and Brain Edema during Cerebral IschemiaReperfusion Injury Probably by Reduction of Interleukin-6 and Matrix Metalloproteinase-9 Transcription. J Stroke Cerebrovasc Dis. 2018;27(11):3053-65.

21.Rasouli Vani J, Taghi Mohammadi M, Sarami Foroshani M, Rezazade E. Evaluation of the neuroprotective and antioxidant effects of Dorema aucheri extract on cerebral ischaemiareperfusion injury in rats. Pharm Biol. 2019;57(1):255-62.

22.Mohammadi MT. Overproduction of nitric oxide intensifies brain infarction and cerebrovascular damage through reduction of claudin-5 and ZO-1 expression in striatum of ischemic brain. Pathol Res Pract. 2016;212(11):959-64.

23.Mohammadi MT, Dehghani GA. Nitric oxide as a regulatory factor for aquaporin-1 and 4 gene expression following brain ischemia/reperfusion injury in rat. Pathol Res Pract. 2015;211(1):43-49.

24.Darabi S, Mohammadi MT. Fullerenol nanoparticles decrease ischaemia-induced brain injury and oedema through inhibition of oxidative damage and aquaporin-1 expression in ischaemic stroke. Brain Inj. 2017;31(8):1142-50.

25.Palmer CN, Hsu M-H, Griffin KJ, Raucy JL, Johnson EF. Peroxisome proliferator activated receptor- $\alpha$ expression in human liver. Mol Pharmacol. 1998;53(1):14-22.

26.Vani JR, Mohammadi MT, Foroshani MS, Jafari M. Polyhydroxylated fullerene nanoparticles attenuate brain infarction and oxidative stress in rat model of ischemic stroke. EXCLI J. 2016;15:378-90.

27.Losey P, Ladds E, Laprais M, Geuvel B, Burns L, Bordet R, et al. The role of PPAR activation during the systemic response to brain injury. J neuroinflammation. 2015;12(1):99.

28.Besson VC, Chen XR, Plotkine M, Marchand-Verrecchia C. Fenofibrate, a peroxisome proliferator-activated receptor alpha agonist, exerts neuroprotective effects in traumatic brain injury. Neurosci Lett. 2005;388(1):7-12.

29.Chen XR, Besson VC, Beziaud T, Plotkine M, Marchand-Leroux C. Combination therapy with fenofibrate, a peroxisome proliferator-activated receptor alpha agonist, and simvastatin, a 3-hydroxy-3-methylglutaryl-coenzyme A reductase inhibitor, on experimental traumatic brain injury. J Pharmacol Exp Ther. 2008;326(3):966-74.

30.Zhu Q, He G, Wang J, Wang Y, Chen W. Protective effects of fenofibrate against acute lung injury induced by intestinal ischemia/reperfusion in mice. Sci Rep. 2016;6:22044.

31.Yaribeygi H, Mohammadi MT, Sahebkar A. PPAR-alpha Agonist Improves Hyperglycemia-Induced Oxidative Stress in Pancreatic Cells by Potentiating Antioxidant Defense System. Drug Res. 2018;68(6):355-60.

32.Zhang Y, Cui Y, Wang XL, Shang X, Qi ZG, Xue J, et al. PPARalpha/gamma agonists and antagonists differently affect hepatic lipid metabolism, oxidative stress and inflammatory cytokine production in steatohepatitic rats. Cytokine. 2015;75(1):127-35.

33.Gautier S, Ouk T, Petrault M. PPAR-Alpha Agonist Used at the Acute Phase of Experimental Ischemic Stroke Reduces Occurrence of Thrombolysis-Induced Hemorrhage in Rats. PPAR Res. 2015;2015:246329.

34.Lakshmi SP, Reddy AT. PPAR Agonists for the Prevention and Treatment of Lung Cancer. PPAR Res. 2017;2017:8252796.

هبله علمى دانشكاه علوه بِزشكى كردستان / دوره بيست و شش / دهر و آبان م.ع| 
تاثير فنوفيبرات بر ميزان ضايعم...

35.Sarnelli G, D'Alessandro A, Iuvone T, Capoccia E, Gigli S, Pesce M, et al. Palmitoylethanolamide modulates inflammation-associated vascular endothelial growth factor (VEGF) signaling via the Akt/mTOR pathway in a selective peroxisome proliferator-activated receptor alpha (PPAR- $\alpha$ )-dependent manner. PLoS One. 2016;11(5):e0156198. 